$\begin{array}{ll}\text { Abstracta Iranica } & \begin{array}{l}\text { Abstracta Iranica } \\ \text { Revue bibliographique pour le domaine irano-aryen }\end{array} \\ & \text { Volume } \mathbf{2 7} \mid \mathbf{2 0 0 6} \\ & \text { Comptes rendus des publications de } \mathbf{2 0 0 4}\end{array}$

\title{
La Cilicie à l'époque achéménide. Paris, de Boccard, 2004, 329 p.
}

Rémy Boucharlat

\section{OpenEdition}

1 Journals

Édition électronique

URL : http://journals.openedition.org/abstractairanica/5689

DOI : 10.4000/abstractairanica.5689

ISSN : 1961-960X

Éditeur :

CNRS (UMR 7528 Mondes iraniens et indiens), Éditions de l'IFRI

\section{Édition imprimée}

Date de publication : 15 mai 2006

ISSN : 0240-8910

\section{Référence électronique}

Rémy Boucharlat, «La Cilicie à l'époque achéménide. Paris, de Boccard, 2004, 329 p. », Abstracta Iranica [En ligne], Volume 27 | 2006, document 65, mis en ligne le 02 janvier 2007, consulté le 25 septembre 2020. URL : http://journals.openedition.org/abstractairanica/5689 ; DOI : https://doi.org/10.4000/ abstractairanica.5689

Ce document a été généré automatiquement le 25 septembre 2020.

Tous droits réservés 


\title{
La Cilicie à l'époque achéménide. Paris, de Boccard, 2004, 329 p.
}

\author{
Rémy Boucharlat
}

1 Voici une étude régionale telle qu'on en souhaiterait pour chacune des satrapies de l'empire achéménide, qui vient s'ajouter à la monographie récemment consacrée à Sardes achéménide par E. Dussinbere. La documentation sur la Cilicie n'est ni meilleure ni pire que celle des régions occidentales de l'empire qui l'entourent. L'archéologie fournit des données pour les périodes antérieures et postérieures, et bien entendu pour l'époque achéménide. La région n'est pas souvent citée par des auteurs anciens, mais elle est connue également à travers un corpus de textes variés (hittites, égyptiens, bibliques, assyro-babyloniens), et des inscriptions phéniciennes, araméennes et grecques; enfin, la Cilicie a émis de la monnaie en quantité importante (émissions municipales, satrapiques ou liées aux campagnes militaires) - la numismatique est même une des sources documentaires majeures pour cette région, en même temps qu'elle est une spécialité de l'A.

2 Comme on pouvait l'espérer, la région est traitée plus largement que pour la seule période achéménide, celle-ci étant replacée dans la durée (voir par ex. la $2^{\mathrm{e}}$ partie intitulée «De Nabonide à Alexandre»). Cela vaut pour l'étude du peuplement de la Cilicie réunie seulement à l'époque achéménide en une unité administrative aussi bien que pour celle de la numismatique. L'A., disciple de P. Briant, livre une véritable monographie, complétée par une liste des inscriptions araméennes, un petit catalogue de monnaies et quelques cartes. 
INDEX

Thèmes : 3.2.1. Elam

\section{AUTEURS}

RÉMY BOUCHARLAT

IFRI-CNRS - Téhéran-Lyon 